\title{
War 3.0: The Indonesia Challenge Against Hoax, Hate Speech and Social Media Abuse
}

\author{
Sirajuddin $^{1}$; Sitti Utami Rezkiawaty Kamil ${ }^{1 \text {; }}$ S Sutiyana Fachruddin \\ ${ }^{1}$ Department of Journalistic, Universitas Halu Oleo, Kendari, Indonesia \\ a Corresponding author: timtam.kamil@gmail.com
}

\begin{abstract}
Social media as part of the information communication technology, provides a space to argue on thoughts that had not previously been disclosed. It is moving very fast and become a new space of expression for the society. The phenomenon of social media today is increasingly widespread, not only become a place to make friends but also transformed into a new media that even used as a reference news, information and knowledge. Facebook as a social media with the largest users in Indonesia become a new media to influence public opinion, mobilize the masses and provide moral pressure on a conflict or cases. The era of information disclosure and freedom of speech seemed to be a double-edged sword. On one side it is advantageous but on the other side it could be detrimental. Using the concept of pataphysics, this research tries to see how the Indonesian people are challenged to face the "flood of information" in social media and against the hoax, hate speech and social media abuse. Pataphysics tends to eliminate existing ones and hold ones that do not exist. The growing virtual era makes the dominance of physical and metaphysical power replaced by the power of image (pataphysics). The image that was originally the medium for message delivery, now becomes the message itself. Pataphysics in social media in recent days drove netizens familiar with the most recent Pataphysics products such as hoax, hate speech and social media abuse.
\end{abstract}

Keywords—social media, hoax, hate speech, facebook

\section{INTRODUCTION}

The evolution of modern technology helped change the habits and lifestyles of society. This is happening evenly in the world, and also in Indonesia. This also has implications for changing the way people access and consume news and information. Communications power is on rise, internet has touched and transformed every aspect of human life in present times. The Internet is a brand-new fertile ground where things can grow and the web is the first thing that grew there [1].

The social media phenomenon is increasingly widespreadand used as a reference news, information and knowledge. It's ability to influence public opinion can mobilize the masses and provide moral pressure on a conflict or case. Among the social media, the most phenomenal is facebook. In 2017, it have reached 111 million users in Indonesia.

Social media as part of information technology innovation, provides space for someone to voice his/her thoughts that previously may never be heard. In Indonesia it was noted that social media has been used for the mobilization of netizen opinion to give moral pressure.

In addition to mass movements to provide moral pressure, the presence of social media in Indonesia also gives effect to the political, social, cultural and economic changes, most strikingly of course we can see today social media shifts and penetrates the boundaries of hierarchical interaction patterns into egalitarian, Both in political and cultural space. An ordinary citizen can directly criticize and communicate with his President simply by sending a mention to the President on his fanpage on facebook. What a freedom and openness that breaks down the boundaries. Welcome to the 3.0 era

\section{RESEARCH METHOD}

In this study, researchers used a qualitative approach. This research produces descriptive data in the form of written data or verbal of the people and behavior that can be taken. This type of research describes a phenomenon or event that occurs at this time. Bogdan and Taylor (1992) explain that Qualitative research is the research that produces data descriptive form of words written or spoken of people or behaviors observed. This approach is directed to the individual's background in a manner intact (holistic) [2].

Using the concept of pataphysics, this research tries to see how the Indonesian people are challenged to face the "flood of information" in social media facebook and against the hoax, hate speech and social media abuse. Pataphysics tends to eliminate existing ones and hold ones that do not exist.

\section{RESUlT AND DISCUSSION}

\section{Social Media Pataphysics}

The era of information disclosure and freedom of speech seemed to be a double-edged sword. On one hand it is advantageous but on the other side it could be detrimental. It is now very easy to find netizens attacking and harassing each other. In Indonesia, attacking and harassing each other in social media increasingly tapered during the Presidential election in 2014. At that time netizen split between supporters Jokowi and Prabowo. Black campaigns and fake news roam easily during the campaign season plus more mutual blasphemy occurred between supporters. It's a Pataphysics, a state full of absurdity where reality is actually covered by reality image. In pataphysics, an image of reality is the most dominant thing and 
the power of manipulative image being in semiotic level. Pataphysics is the science of imaginary solutions, which are characterized by their virtuality. Pataphysics tends to eliminate existing ones and hold ones that do not exist [3].

The growing virtual era makes the dominance of physical and metaphysical power replaced by the power of image. The image that was originally the medium for message delivery, now becomes the message itself. Pataphysics in social media in recent days drove netizens familiar with the most recent Pataphysics products such as hoax, hate speech and social media abuse.

From the modernism you want, you get the postmodernism you deserve. The rising of political tension in Indonesia also disturbing the virtual universe, hoax scattered uncontrollably, hate speech transformed into something commonplace and social media abuse has become the daily behavior the majority of Indonesian netizens in social media. Social media no longer keeps netizens close, but brings them into a deep polarization gap. If this is not controlled, then the most obvious is social disharmony throughout social media.

The result of our social media today is full of the power of manipulative imagery that seems to be reality and ultimately understood as the real reality, as a result of a cultivation of reality then transforms into the pataphysics in which the power of image shapes and defines reality.

\section{The era of hoaxes}

In the era of pataphysics we tend to be difficult to distinguish where is the real informations and what is the fake one. In today's age of cyberspace, there is no monopoly of information. Anyone can be a news or informer, both professional and ordinary people. Factual news, accurate, important, or even hoax Flare up in social media. Truth information from various perspectives is presented. So the recipient of information becomes king in free market logic. Because information is no longer a perspective giver, but the information perspective is determined by the recipient. What kind of desired information is available, just click away. Truth is relative, the most important is the satisfaction of the recipient of the information. In addition to the fast sharing habits in social media, the reading patterns of society also changed completely. Based on data from 2017 revealed by Masyarakat Telematika (Mastel) most of the portion of hoax news spread in Indonesia comes from politically charged, the number reached $91.80 \%$. While in the second position, the topic around SARA is also quite dominating, the number reached $88.60 \%$.

Indonesia is bombarded by hoax news in social media. Pataphysics in social media also encourage hoax progressively rolling blindly. The media increasingly controlled by the Partisipanship allegedly because it has been co-opted interests and transactions, this is where hoax created spaces are produced and distributed. The saracen case at least makes us open our eyes wide if hoaxes are now produced intentionally and become a professional industry run by certain actors in order to divide the nation. Saracen itself is a syndicate of hate speech and hoax spreader that operated since 2015 and itcase successfully revealed by Indonesian police. This syndicate is deployed in the Facebook group and consists of more than 800 thousand accounts.

Which makes it even more ironic that netizens mostly neglect to verify and only share articles or news information from the media simply by looking at their political suit only. Indonesians behavior in social media are reposting and broadcasting, if $30 \%$ of Saracen group members do these two things, it is certain that the spread of hoax potentially greatly provoking the Indonesian people. Hoax information has divided the public and this syndicate shows that the flood of hoaxes and various provocations of hatred and racial prejudice are not merely individual actions but well organized and commercialized.

\section{Hate Speech: The Hate Spreader}

Hoax phenomenon is not the only thing, Hate speech cases are also rise in social media. Hate Speech in Indonesia counts as a crime in the form of humiliation, defamation, contempt, disrespectful acts, provoking, inciting, spreading false news, and all of the above acts have a purpose or may impact on acts of discrimination, violence, disappearance of life, and or social conflict.

Case that became viral in social media and attracted enough attention was Buni Yani. He was caught in the case of alleged hate speech after uploaded a video of Ahok's speech on facebook, which at that time, Ahok still be a former governor of Jakarta. In 2017 there was the Nasdem Party politician Viktor Bungtilu Laiskodat who was reported to the police as a result of his speech that was supposed to incite the people to violence and spread hatred. At the same year, Jonru Ginting was reported to the police because he was considered to have published a provocative and persistent hate speech on facebook. A person who is deemed to have violated the Information and Electronic Transaction Law may be sentenced to a maximum of 6 years in jail and / or a maximum fine of Rp 1 billion if proven to disseminate information whose purpose is to generate hatred based on SARA issues.

Kapolri issued a circular letter to fight the hate speech that was out of control. In the era of globalization, the law must be able to support and balance the growth of the technology world. In order to avoid conflicts within the community, it is necessary to enact laws that enable people to be more accountable and smarter in expressing their opinions according to cultural values. Whereas the meaning of freedom of speech in a democratic society is a responsible freedom. With this Circular Letter, it is expected that all police officers can take firm action against anyone who uses hate speech. The action is prioritized precisely preventive. If it has not been effective then the police officers can take legal action. This Circular Letter is also expected to make the community more ethical and intelligent in expressing public opinion.

\section{A new kind of violence: Social Media Abuse}

There several challenges exist in social media, where users actively create the content of information messages and modify as desired. The phenomenon of the circulation of hoax and hate speech in social media media also gave birth to new types of violence in social media. This phenomenon is actually raised by someone who is not responsible for attacking a person or a 
group of people. Ironically the phenomenon of social media violence is regarded as a natural thing and a commodity that is often commodified. The most concrete form of social media abuse can be seen in detail and vulgar through the comment field. A unique phenomenon that can be observed here, namely freedom of speech. Those in the real world are afraid to argue, as if getting room for expression in social media. But on the other hand, because too freely expression makes people forget ethics in expressing opinions. Bullying words often appear in the social media comment field. The effects of the commodification of social media violence gave rise to verbal violence. The debates raised in social media are often followed by coercion of wills and opinions. Verbal abuse in social media is easier to do than conventional violence because the perpetrator does not need to face-to-face with his target victim. They can say bad things and easily intimidate their victims because they are behind a computer screen or staring at a mobile phone screen without having to see the consequences of the victim.

\section{CONCLUSION}

In the face of war 3.0 Against Hoax, Hate speech and Social media need a strategy for this digital war can be won. Media literacy becomes an absolute necessity in an intensive and sustainable manner in society. Media literacy is the ability to understand, analyze, and deconstruct media imagery. The ability to do this is aimed at audiens as media consumers becoming aware of how media is constructed and accessed. Through literacy media, people can improve their intellectual by actively seeking information that suits their needs based on existing references, so that the information obtained can answer the needs sought by individuals as members of the society itself.

Our public literacy is low for information literacy, media literacy, and now even lower in the field of social media literacy. In the information age, social media has an overwhelmingly powerful effect on people's lives, for that we need to move the media literacy thoroughly in society.
The government must actively make regulations and policies related to the transactions of information in social media. Government regulations and policies must coincide with technological advances. The government should also be urging social media application providers to take responsibility in combating hoax, hate speech and social media abuse. What has happened so far in Indonesia, only the makers of hoaxes, hate speech and social media abuse that can be processed, social media application providers must take responsibility. Regulation and laws could help, but the challenge is in implementation of laws, the Indonesian Electronic Information and Transaction Law has not specifically formulated the responsibility of the social media application provider company, this law only generalizes social media users, social media companies, news portals, e-commerce, search engine companies, And the page manager as the organizer of the electronic system. In addition to regulations and policies, the Government of Indonesia should also rush to develop infrastructure to supports the development of digital media, one day Indonesia can have a national search engine or a local social media.

It is not impossible that the 2019 presidential election challenge will become more severe. The dynamics that occur in social media today should be observed and immediately looked for solutions, if not win this "digital war 3.0" then we will be divided.

\section{REFERENCES}

[1] J. Brockman, Is the Internet Changing the Way You Think?: The Net's Impact on Our Minds and Future, 2011 ed, New York: Harper Perennial, 2011.

[2] R.C. Bogdan and S.J. Taylor, 1992, Introduction to Qualitative Research Methotds: A Phenomenological Approach in the Social Sciences, New York: John Wiley \& Sons, 1975.

[3] A. Hugill, Pataphysics: A Useless Guide, New York: MIT Press, 2015. 